\title{
THE DISTRIBUTION AND BIOCULTURAL VALUE ASSESSMENT OF SWEET CHESTNUT (Castanea sativa Mill.) IN THE CADASTRAL DISTRICTS OF STREDNÉ PLACHTINCE AND HORNÉ PLACHTINCE (SLOVAKIA)
}

\author{
MICHAL PÁSTOR, MARTINA SLÁMOVÁ, TIBOR BENČAT̃
}

Department of Landscape Planning and Design, Faculty of Ecology and Environmental Sciences, Technical University in Zvolen, T. G. Masaryka 24, 96053 Zvolen, Slovak Republic; e-mail: michalpastor65@gmail.com, mslamova@ hotmail.com, tibor.bencat@tuzvo.sk

\begin{abstract}
Pástor M., Slámová M., Benčat’ T.: The distribution and biocultural value assessment of sweet chestnut (Castanea sativa Mill.) in the cadastral districts of Stredné Plachtince and Horné Plachtince (Slovakia). Ekológia (Bratislava), Vol. 36, No. 2, p. 130-145 , 2017.

The cadastral districts of Stredné Plachtince and Horné Plachtince are situated in the southern part of the Krupinská Planina Mts. in the Carpathian Mts. and about one-third of both the districts is made up of traditional agricultural landscape. Sweet chestnut finds here suitable natural conditions for its growth. The article focuses on the chestnut biocultural value assessment in the given traditional landscape type. Firstly, the field survey concerning chestnuts and old stables identification and positioning was done. Secondly, the data were processed by the geospatial analysis tools in QGIS aiming at the evaluation of chestnuts and old stables spatial distribution in the study area. Thirdly, the chestnut biocultural value was assessed and the modification of current boundary of the given landscape type was proposed. Chestnuts most frequently occurred in the extensively used CLC patches with pastures and heterogeneous agricultural areas - "Land principally occupied by agriculture with significant areas of natural vegetation", in parallel coinciding with HNV farmlands and habitats of European importance and with local occurrence of the protected bat species. Chestnuts found in the vicinity of old stables partially confirmed their specific function in cattle breading in the past. We can conclude that sweet chestnut supports the value of the traditional landscape type of "pastoral land with meadows" and its current area could be extended correspondingly to our results.
\end{abstract}

Key words: sweet chestnut, traditional land use, old stables, biocultural value, high nature value farmlands, biotopes.

\section{Introduction}

Sweet chestnut (Castanea sativa Mill.) has been cultivated particularly across the Mediterranean Basin in the areas with abundant precipitation and its geographical range is closely associated with the activities of pre-industrial traditional agrarian societies (Conedera et al., 2004a). It is the only native species of the genus in Europe (Conedera, Krebs, 2008). Cultivation of 
chestnut has a long tradition and deep roots in many European countries which can be divided into three categories: (i) countries with a strong chestnut tradition (e.g. Italy, France, southern Switzerland, Spain, Portugal, and Greece); (ii) countries with a partially developed chestnut tradition (e.g. England, Slovenia, Croatia, Turkey and Georgia); (iii) countries where chestnut occurs only sporadically (e.g. Hungary, Bulgaria and Belgium) or has been recently introduced (e.g. Slovakia and the Netherlands) (Conedera et al., 2004b, 2016) .

Sweet chestnut is an important European woody plant with ecological, cultural, aesthetical, and historical values (Krebs et al., 2012). Due to its beauty, it is considered to be a landscape forming element (Heiniger, Conedera, 1992). It represents an invaluable bridge between cultivation and the historical heritage. The chestnut landscape offers great benefits in terms of social welfare (Bounous, 2014). From a socio-economic point of view, chestnut can play an important role in promoting local identity and social cohesion as well as in helping to preserve the landscape where cultivation of this species is well-established (Torello Marinoni et al., 2014).

Sweet chestnut typically grows in the agricultural landscape on mountain foothills with warm climates in the south and southeast of Slovakia at altitudes of 200-500 m ASL (Bolvanský et al., 2008). It is a marginal nut crop and it is not a forest forming tree species. The mutual influence of unfavourable soil-climatic conditions and the impacts of diseases limits its growth here. Nevertheless, based on the known literature (Heiniger, Conedera, 1992; Bounous et al., 1999; Michon, 2011; Conedera et al., 2004b), we intended to prove that the quality of the studied traditionally used agricultural landscape is interlinked with sweet chestnut having biocultural values.

Preservation of common landscape values, including values which are not under special protection of the law, is necessary for the preservation of European landscape diversity. Both the studied cadastral districts of Stredné Plachtince and Horné Plachtince represent examples of cultural landscapes without a particular protection; however, a sense of belonging to sweet chestnut manifested by residents as well as natural and cultural values interlinked with chestnut make this "common landscape" a unique one in Slovakia.

\section{The aims}

The main aim of the work is to assess the chestnut biocultural value in the traditional landscape types which are present in the study area. We had an ambition proving sweet chestnut to be a valuable feature of traditional landscapes.

Yet no European landscape typology with a specific focus on the cultural heritage exists. However, some initiatives such as the HERCULES project presented the development of a new typology of cultural landscapes focusing specifically on the identification of cultural heritage within the landscapes of Europe (Tieskens et al., 2014). Kozová et al. (2009) have pointed out that the areas with a preserved traditional way of farming in the landscape are understood to be significant not only from an ecological point of view, but also from a cultural, historical, aesthetic, and landscape-ecological ones and they have to be identified for the purposes of a future typology of cultural landscapes in Slovakia.

Regarding the proposed classification criteria for identifying cultural landscape types (Kozová et al., 2009), we have examined historical agricultural buildings, chestnuts and chestnut 
area formations holding natural and cultural values related to chestnuts in the contemporary land use patches (CLC) (EEA, 2016a) in the study area of Stredné and Horné Plachtince. The concept of biocultural rights combines nature with culture and it takes into consideration the past, the present, and the future, and the values of "special", the indigenous elements that are indispensable to the diversity of our universe (Chen, Gilmore, 2015). In the context of the assessed factors, the chestnut biocultural value was comprehensively examined in the study area.

The natural values were represented by high nature value (HNV) farmlands (Keenleyside et al., 2014), (EEA, 2016b) and habitats of European importance (Galvánek, Lasák, 2011).

The cultural values related to chestnuts were represented by historical farm buildings in the vicinity of chestnuts dispersed in the countryside. The residents of villages usually owned agricultural plots with fields, meadows, pastures and vineyards where specific seasonal dwellings called "chišky" and "koňice" were built (Chovanová et al., 2006). The English equivalent of both the words for this type of buildings is a stable. "Koňice" were used for cattle breeding. The consideration of cultural criterion for the chestnut biocultural value assessment followed the findings of previous works (Michon, 2011; Krebs et al., 2012). Giant (remarkable) chestnut trees were cultivated as single trees usually standing on a valuable pasture or agricultural land with a gentle slope in relation to particular human features such as settlements, property boundaries, and trails (Krebs et al., 2012).

For the chestnut biocultural value assessment in the studied landscape types with traditional land use, the selected criteria were applied. Based on the results, modifications of the current boundaries of traditional landscape types were proposed. The traditional landscape types were adapted from the Atlas of the Slovak Republic (Miklós, Hrnčiarová, 2002) and downloaded as the raster online image of traditional landscape types.

Chestnut individuals and its area formations were identified and positioned in 6 cadastral districts (Dolné Príbelce, Horné Príbelce, Dolné Plachtince, Stredné Plachtince, Horné Plachtince, and Modrý Kameň). The cadastral districts represented a broader study area. The geospatial analysis of the chestnut distribution within CLC 2012 patches, HNV farmlands, and habitats of European importance and its relationship to historical agricultural buildings were processed within two cadastral districts of Stredné Plachtince and Horné Plachtince (Fig. 1).

$\mathrm{T}$ a b l e 1 . The comparison of traditional landscapes in Slovakia, a broader study area and the cadastral districts of Stredné Plachtince and Horné Plachtince.

\begin{tabular}{|c|c|c|c|c|c|}
\hline \multicolumn{2}{|c|}{ Slovakia } & \multicolumn{2}{|c|}{$\begin{array}{c}\text { A broader study area } \\
\qquad 8,809.42 \mathrm{ha} \\
\end{array}$} & \multicolumn{2}{|c|}{$\begin{array}{c}\text { Stredné Plachtince } \\
\text { and Horné Plachtince } \\
\quad 3,138.00 \text { ha }\end{array}$} \\
\hline \multicolumn{6}{|c|}{ Traditional landscapes $^{\star}$} \\
\hline $\begin{array}{c}\text { Pastoral land } \\
\text { with meadows } \\
\text { [ha]; [\%] }\end{array}$ & $\begin{array}{l}\text { Agricultural land } \\
\text { with scattered } \\
\text { settlements } \\
\text { [ha]; [\%] }\end{array}$ & $\begin{array}{c}\text { Pastoral land } \\
\text { with meadows } \\
\text { [ha]; [\%] }\end{array}$ & $\begin{array}{c}\text { Agricultural land } \\
\text { with scattered } \\
\text { settlements } \\
\text { [ha]; [\%] }\end{array}$ & $\begin{array}{c}\text { Pastoral land } \\
\text { with meadows } \\
\text { [ha]; [\%] }\end{array}$ & $\begin{array}{c}\text { Agricultural land } \\
\text { with scattered } \\
\text { settlements } \\
\text { [ha]; [\%] }\end{array}$ \\
\hline $\begin{array}{c}289,590.15 \\
5.89\end{array}$ & $\begin{array}{c}235,940.46 \\
4.80\end{array}$ & $\begin{array}{c}1,033.16 \\
11.72\end{array}$ & $\begin{array}{c}593.56 \\
6.74\end{array}$ & $\begin{array}{c}\text { 1,033.16; } \\
32.92\end{array}$ & $\begin{array}{c}593.56 \\
18.91\end{array}$ \\
\hline
\end{tabular}

Note: ${ }^{*}$ - The data were derived from the Landscape Atlas of the Slovak Republic published by Miklós, Hrnčiarová, 2002. Source: Authors 


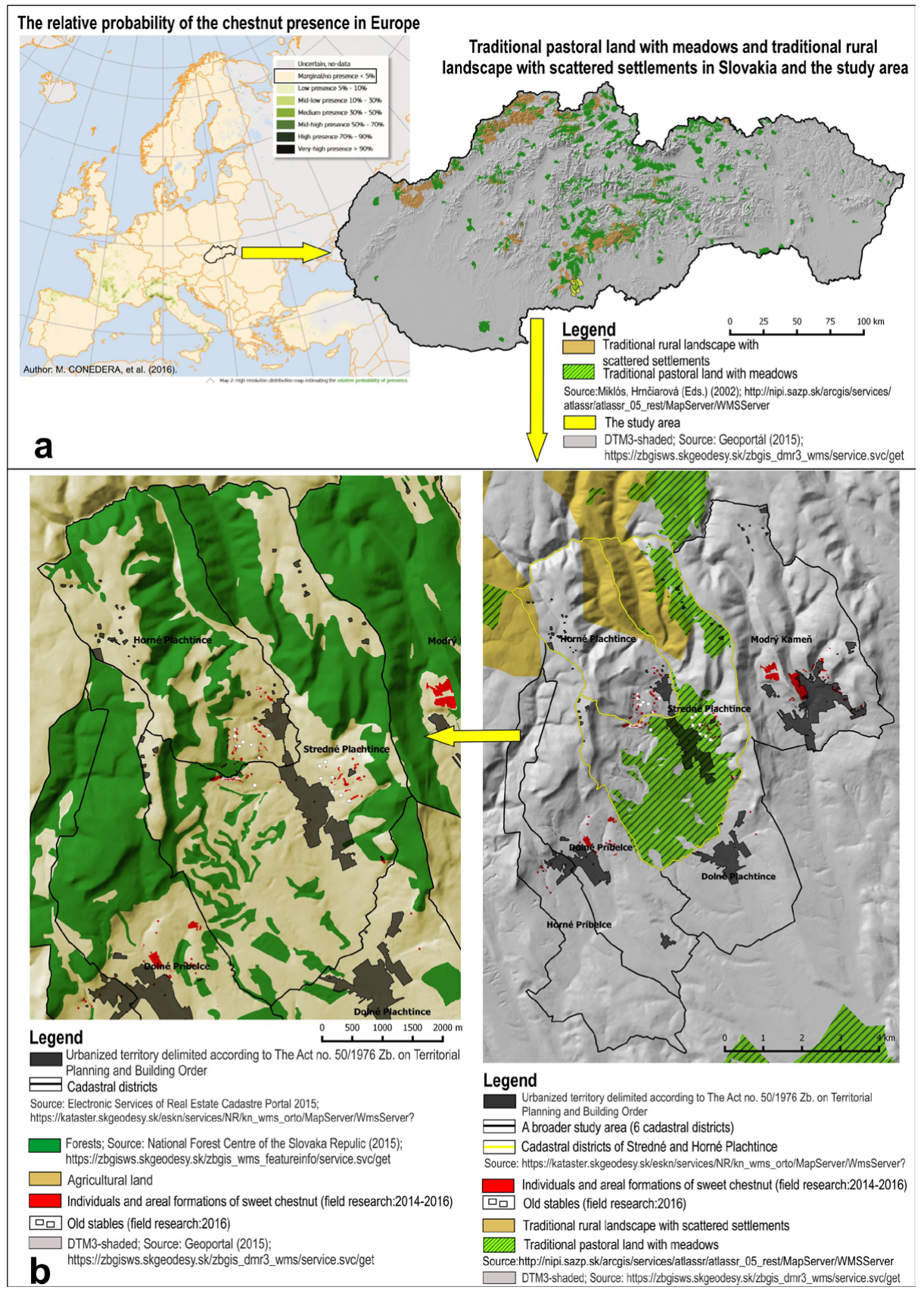

Fig. 1a,b. The chestnut distribution in Europe (Conedera et al., 2016) and in the study area (1a). Traditional landscapes and current land use of the study area (1b). 
We expected the chestnut occurrence in traditional agricultural landscapes as observed by Štefunková et al. (2013) and Špulerová et al. (2014) in similar localities in Slovakia. More than half the aforementioned two cadastral districts is covered by traditional landscapes - pastoral land with meadows (32.92\%) and traditional agricultural one with scattered settlements (18.91\%) (Table 1).

\section{The study area}

The study area lies on the geographical border of the Pannonian and the Carpathian regions. Uplands of the Krupinská planina Mts. (Čebovská pahorkatina Mts. and Pôtorská pahorkatina Mts.) constitute specific conditions for thermophilic and xerothermic plant and animal species (Franc, 2010). It is characterized by high biodiversity which is concentrated, inter alia, also in the Special Areas of Conservation of Natura 2000 (Kušík, Pástor, 2016). Warm climate, gentle slopes of foothills covered by nutritious cambisols on neovolcanic rocks (the data were derived from the Atlas of the Slovak Republic published by Miklós, Hrnčiarová, 2002) predisposed this area for growing chestnut which, in general, rarely occurs in Slovakia. Chestnut trees have been planted in private vineyards and orchards since the $16^{\text {th }}$ century. Historically, its introduction into the study area was probably related to monarchs' activities at the medieval castle of Modrý Kameň (Pástor et al., 2015). The chestnut festivities in the town of Modrý Kameň take place yearly and present an example of a living tradition connected with the chestnut harvest (Kosňovská, 2013).

\section{Material and methods}

In the following sections, we describe: (1) the data collection procedure, techniques and material used during the field inventory, focusing on identification and positioning of chestnuts and agricultural buildings; (2) data processing in the geographic information systems (GIS) by the geospatial analysis tools focusing on the evaluation of spatial distribution of chestnuts and historical agricultural buildings in the study area; (3) the interpretation of the chestnut biocultural value and proposals for the modification of current boundary of the given traditional landscape types.

\section{The field inventory}

The field inventory was done within the period from 2014 to 2016 and primarily concentrated on the chestnut flowering phase as the individuals were easily recognizable in the countryside. We have documented both living and dead trees. Furthermore, buildings with an agricultural function (stables, vine cellars and storages) were identified and positioned in the field. A touristic Global Navigation Satellite System (GNSS) Garmin (2010) was used for the positioning of the studied buildings (an inaccuracy of $3 \mathrm{~m}$ was declared by the manufacturer). Short interviews with the locals helped us identify the ruined historical agricultural buildings in the field.

\section{Evaluation of the spatial distribution of chestnuts and historical agricultural buildings in the study area}

For geodata processing, we used QGIS 2.12.2 Lyon. The coordinate reference system S-JTSK East North (Greenwich) (EPSG code 102067) was applied. GNSS data on chestnuts and agricultural buildings were imported into QGIS and their position was corrected according to orthophotomaps (2010). The orthophotomaps were provided by the Technical University in Zvolen within the project CEX ITMS 26220120069, the Centre of Excellence for Decision Support in Forest and Country. The public raster maps were accessed by a QGIS web map server (WMS) client, further adjusted for the study area (transformed into the S-JTSK coordinate system and cropped), and selected data were digitised and saved as vector files. A DTM 3.5 raster (hillshade) (GEOPORTÁL, 2015) was used as a background raster image for the figures and maps in the article. 
The number of chestnut individuals and the area of chestnut formations [ha] characterised the chestnut distribution within the examined units (CLC 2012 patches, HNV farmlands, and habitats of European importance).

Current forest plots were digitised from online images of the public raster maps provided by the National Forest Centre (NFC, 2015). The data layers of the urbanized territory and cadastral districts were downloaded from the cadastral portal of the Slovak Republic (ESKN PORTAL, 2015). The agricultural land was derived consequently from previously elaborated vector layers.

CLC 2012 patches and HNV farmlands were interpreted (GeoTiff format was converted to a vector layer) from the seamless raster database (EEA, 2016a). All features in databases were classified and digitised on the basis of satellite images with a $100 \mathrm{~m}$ positional accuracy and used a minimum mapping unit of 25 ha for area phenomena and a minimum width of $100 \mathrm{~m}$ for linear phenomena. The following CLC codes were applied: $112 ; 211 ; 221 ; 222$; $231 ; 242 ; 243 ; 311 ; 324$.

The habitats of European importance were digitised from a map available on the Daphne organisation website (Galvánek, Lasák, 2011). In the study area, the habitat of Lowland Hay meadows (No. 6510) was identified.

Historical agricultural buildings were firstly identified in the historical topographic maps with a scale of 1:25,000 (1952-1957) (SEA, 2015). All the buildings were vectorised. Consequently, we made a vector layer containing only old stables that were verified and positioned in the field by the GNSS. The position of the stables was adjusted according to the current land parcels that were available as online raster maps and provided by the Electronic Services of Real Estate Cadastre Portal (ESKN, 2015). We have documented the construction of old stables that indicated usage for livestock (Fig. 2a), the equipment indicated beekeeping (Fig. 2b) and cattle breeding (Fig. 2c). According to the aforementioned signs, we confirmed a specific type of agricultural buildings locally called "koňice", where the occurrence of chestnuts was expected.
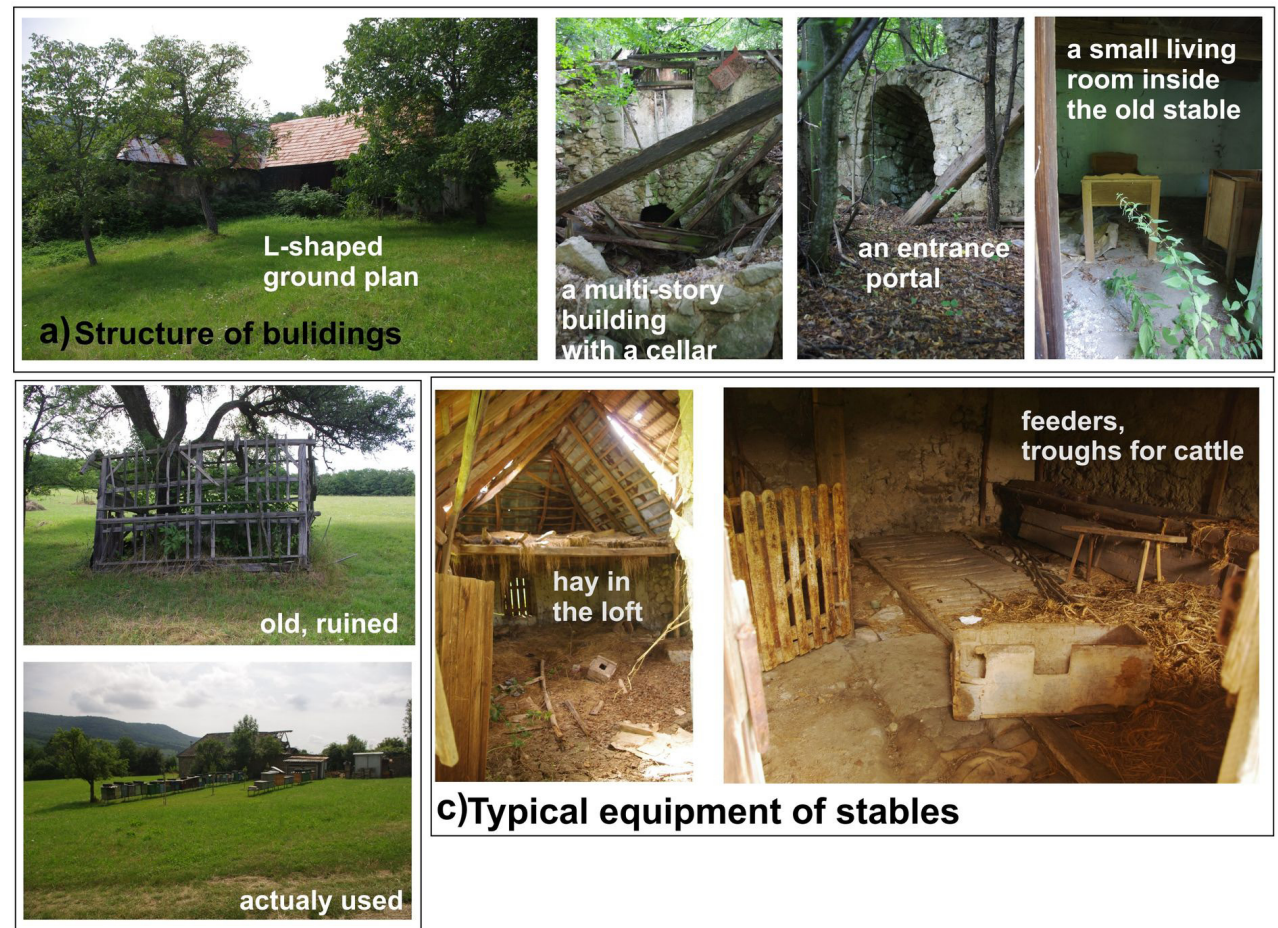

\section{b) Beehives}

Fig. 2a,b,c. Construction material of the old stables (2a); beekeeping constructions (2b); technical equipment for cattle breeding $(2 c)$. 
The geospatial relationship between chestnuts and old stables was tested by the distance matrix using the Distance Matrix Analysis Tool in QGIS. We calculated the shortest neighbour distances between old stables and chestnut solitaires and old stables and chestnut area formations (represented by the centroids of their polygons). A linear matrix type was applied with the formula $n^{\star} k \times 3$, where " $n$ " was a total number of points and only the first nearest " $k$ " target points were taken into account. The geodata were further processed in MS Excel 2010 and interpreted in a histogram of the nearest distances.

\section{The assessment of chestnut biocultural value within traditional landscape types}

All vector layers holding the chestnut biocultural values were overlapped with the CLC 2012 patches and within each category of CLC 2012, we calculated:

- the number of chestnut individuals;

- the area of data layers (chestnut area formations, HNV farmlands and habitats of European importance) in absolute [ha] and relative [percentage] values.

The highest rate of the presence of chestnut individuals and the highest coverages of examined data layers were indicated by the most valuable CLC 2012 category comprising the chestnut biocultural values. As a result, a boundary change for the current traditional landscape types was proposed. Boundaries of traditional landscape types were classified in the Atlas of the Slovak Republic (Miklós, Hrnčiarová, 2002) in a map with a scale of 1:500,000. On the basis of the results achieved at a local scale, we proposed a modification of the traditional landscape type boundary.

\section{Results}

The spatial distribution of chestnuts and old stables in the countryside

We have identified and positioned 101 individuals and 123 area formations (46 ha) of chestnuts in the field within the broader study area. They grow here on mountain slopes at altitudes of 228 to $448 \mathrm{~m}$ ASL. They were predominantly found in the agricultural landscape comprising 69 individuals and 99 area formations; 5 individuals and 10 area formations appeared within forests; 27 individuals and 14 area formations overlapped the urbanized territory.

We identified and positioned 49 individuals and 54 polygons area (6.9 ha) within two cadastral districts of Stredné Plachtince and Horné Plachtince. They grow on mountain slopes at altitudes of 215 to $417 \mathrm{~m}$ ASL in two cadastral districts of Stredné Plachtince and Horné Plachtince. A prevailing number of chestnuts was located in the agricultural landscape (44 individuals, 48 area formations); 5 individuals and 6 area formations appeared within forests; no chestnuts were in the urbanized territory.

Totally, 345 historical agricultural buildings were identified in the historical topographic maps, thereof 38 buildings we verified in the field within Stredné Plachtince and Horné Plachtince, and 26 were confirmed to be old stables.

All chestnuts and historical agricultural buildings are displayed in Fig. 1 and Fig. 4. The analysis of the geospatial relationship between chestnut individuals (49), centroids of its area formations (55) and old stables (26) showed that the most frequent distances of the nearest neighbour ranged from $82.79 \mathrm{~m}$ to $205.18 \mathrm{~m}$ (Fig. 3). While the distance between buildings and chestnuts increased, the frequency of chestnut and old stables decreased. Thus, we assumed that chestnuts were planted in the vicinity of old stables. 


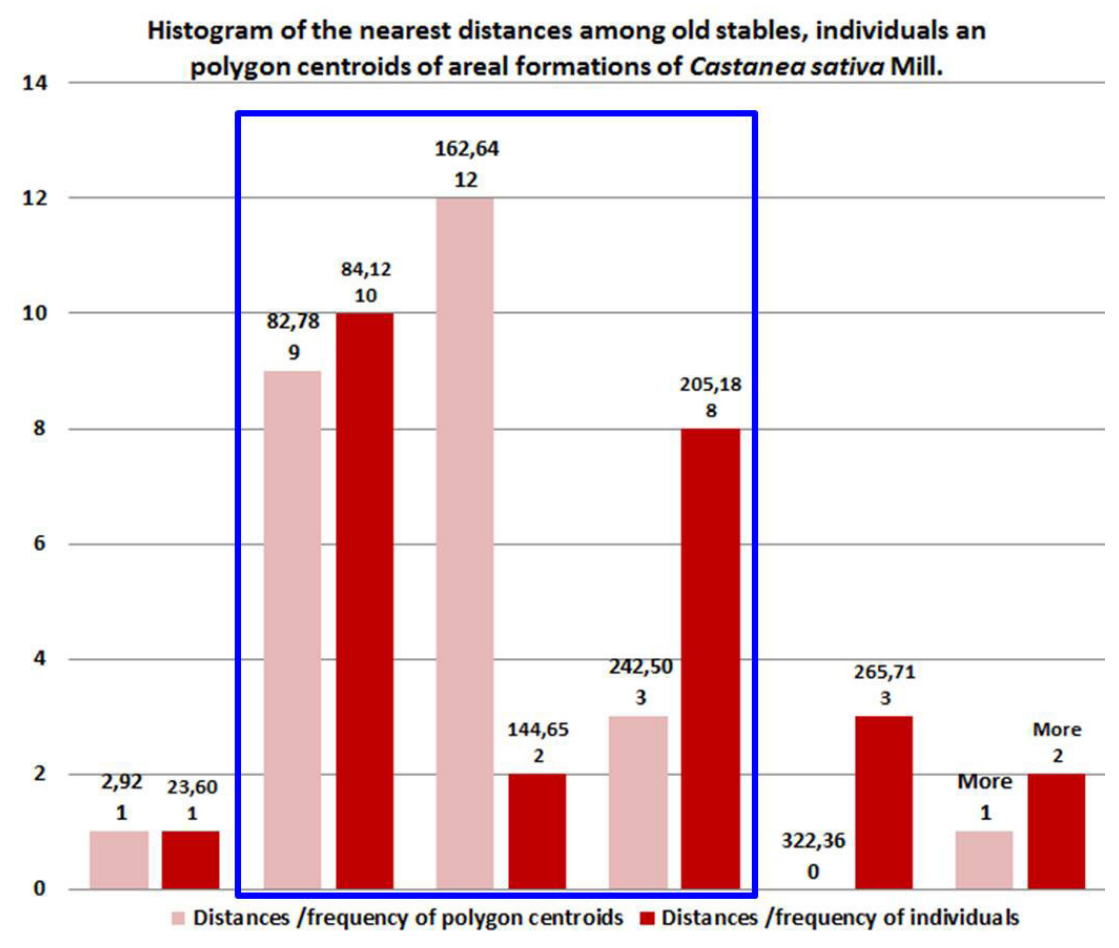

Fig. 3 Histograms of the shortest distances between old stables and chestnuts.

The assessment of chestnut biocultural value in traditional landscape types

Forested land (corresponding mainly with the CLC 2012 category of "Forest and semi- natural areas - Forests - Broad-leaved forest") covered the most extensive area of both the cadastral districts (1,609.69 ha; 51.3\%). On the other hand, the most valuable CLC 2012 patches corresponded with the category of "Agricultural areas - Pastures - Pastures". Despite their relatively lower coverage (286.46 ha; 9.13\%) in comparison to other CLC categories, it showed the highest coverages of HNV farmlands $(200.28$ ha; $50.70 \%)$ and chestnut area formations $(2.53 ; 36.67 \%)$ as well as the highest number of chestnut individuals $(18 ; 36.74 \%)$. The habitats of European importance showed the second largest coverage (141.15 ha; $28.68 \%$ ) in this CLC category. On that basis, we can conclude that category of "Agricultural areas - Pastures - Pastures" was the most valuable.

Furthermore, the second ranked valuable CLC category was "Agricultural areas - Heterogeneous agricultural areas - Land principally occupied by agriculture, with significant areas of natural vegetation" (594.52 ha; 18.95\%). The highest coverage of habitats of European importance (185.62 ha; $37.73 \%$ ) overlapped this CLC category and HNV farmlands had the second largest coverages (169.81ha; $42.98 \%$ ) and the second most frequent was the number of chestnut individuals $(16 ; 32.65 \%)$ here (Table 2$)$. 
$\mathrm{T}$ a b l e 2. The chestnut biocultural value assessment within the CLC 2012 categories.

\begin{tabular}{|c|c|c|c|c|c|c|}
\hline \multirow{2}{*}{\multicolumn{2}{|c|}{$\begin{array}{l}\text { CLC } 2012 \\
\text { Code } 1^{\text {st }}-2^{\text {nd }}-3{ }^{\text {rd }} \text { level area }\end{array}$}} & \multirow{3}{*}{$\begin{array}{c}(\mathrm{ha}) ;(\%) \\
62.12 \\
1.98\end{array}$} & \multirow{3}{*}{$\begin{array}{c}\begin{array}{c}\text { Habitats of } \\
\text { European } \\
\text { importance } \\
\text { area }\end{array} \\
\text { (ha); (\%) } \\
1.21 ; \\
0.25\end{array}$} & \multicolumn{2}{|c|}{$\begin{array}{l}\text { Castanea sativa Mill. } \\
\text { individuals polygons }\end{array}$} & \multirow{3}{*}{$\begin{array}{c}\begin{array}{c}\text { High nature } \\
\text { value farmland } \\
\text { area }\end{array} \\
\text { (ha); (\%) } \\
0 ; 0\end{array}$} \\
\hline & & & & \multirow{2}{*}{$\begin{array}{c}\mathrm{N} ;(\%) \\
3 ; \\
6.12\end{array}$} & \multirow{2}{*}{$\begin{array}{c}\text { (ha); }(\%) \\
0 ; 0\end{array}$} & \\
\hline 112 & $\begin{array}{l}\text { Artificial surfaces - Urban } \\
\text { fabric - Discontinuous urban } \\
\text { fabric }\end{array}$ & & & & & \\
\hline 211 & $\begin{array}{l}\text { Agricultural areas - Arable } \\
\text { land - Non-irrigated arable } \\
\text { land }\end{array}$ & $\begin{array}{c}363.68 \\
11.59\end{array}$ & $\begin{array}{c}20.17 \\
4.09\end{array}$ & $0 ; 0$ & $0 ; 0$ & $0 ; 0$ \\
\hline 221 & $\begin{array}{l}\text { Agricultural areas - Permanent } \\
\text { crops - Vineyards }\end{array}$ & $\begin{array}{c}57.79 \\
1.84\end{array}$ & $\begin{array}{c}6.91 \\
1.41\end{array}$ & $0 ; 0$ & $0 ; 0$ & $0 ; 0$ \\
\hline 222 & $\begin{array}{l}\text { Agricultural areas - Permanent } \\
\text { crops - Fruit trees and berry } \\
\text { plantations }\end{array}$ & $\begin{array}{c}21.77 \\
0.69\end{array}$ & $0 ; 0$ & $0 ; 0$ & $0 ; 0$ & $0 ; 0$ \\
\hline *231 & $\begin{array}{l}\text { Agricultural areas - Pastures - } \\
\text { Pastures }\end{array}$ & $\begin{array}{l}286.46 \\
9.13\end{array}$ & $\begin{array}{c}141.15 \\
28.68\end{array}$ & $\begin{array}{c}18 \\
36.73\end{array}$ & $\begin{array}{l}2.53 \\
36.67\end{array}$ & $\begin{array}{l}200.28 \\
50.7\end{array}$ \\
\hline 242 & $\begin{array}{l}\text { Agricultural areas - } \\
\text { Heterogeneous agricultural } \\
\text { areas - Complex cultivation } \\
\text { patterns }\end{array}$ & $\begin{array}{c}83.17 \\
2.65\end{array}$ & $\begin{array}{l}58.35 \\
11.86\end{array}$ & $\begin{array}{c}8 ; \\
16.33\end{array}$ & $\begin{array}{l}2.01 \\
29.13\end{array}$ & $0 ; 0$ \\
\hline 243 & $\begin{array}{l}\text { Agricultural areas - } \\
\text { Heterogeneous agricultural } \\
\text { areas - } \\
\text { "Land principally occupied by } \\
\text { agriculture, with significant } \\
\text { areas of natural vegetation" }\end{array}$ & $\begin{array}{c}594.52 \\
18.95\end{array}$ & $\begin{array}{c}185.62 \\
37.73\end{array}$ & $\begin{array}{c}16 ; \\
32.66\end{array}$ & $\begin{array}{l}1.04 \\
15.07\end{array}$ & $\begin{array}{c}169.81 \\
42.98\end{array}$ \\
\hline 311 & $\begin{array}{l}\text { Forest and semi natural areas - } \\
\text { Forests - Broad-leaved forest }\end{array}$ & $\begin{array}{l}1609.69 \\
51.3\end{array}$ & $\begin{array}{l}70.6 \\
14.35\end{array}$ & $\begin{array}{c}4 ; \\
8.16\end{array}$ & $\begin{array}{l}1.32 \\
19.13\end{array}$ & $\begin{array}{c}24.05 \\
6.09\end{array}$ \\
\hline 324 & $\begin{array}{l}\text { Forest and semi natural areas - } \\
\text { Shrub and/or herbaceous } \\
\text { vegetation associations - } \\
\text { Transitional woodland-shrub }\end{array}$ & $\begin{array}{c}58.80 \\
1.87\end{array}$ & $\begin{array}{l}8.01 \\
1.63\end{array}$ & $0 ; 0$ & $0 ; 0$ & $\begin{array}{l}0.92 \\
0.23\end{array}$ \\
\hline & Total area & $3138 ; 100$ & $492.02 ; 100$ & $49 ; 100$ & $6.9 ; 100$ & $395.06 ; 100$ \\
\hline
\end{tabular}

Note: ${ }^{\star}$ - Shaded rows of the CLC 2012 patches have indicated the highest rate of all the examined coverages and the number of chestnut individuals.

According to the achieved results, we proposed an extension of the current traditional agricultural landscape type of "pastoral land with meadows" with an area of 1033.16 ha (adopted from the Atlas of the Slovak Republic; Miklós, Hrnčiarová, 2002) to an area of 1136.25 ha. The proposed boundary change does not mean an extensive spreading of the current area. It includes mainly the CLC patches of "Agricultural areas - Pastures - Pastures" and "Agricultural areas - Heterogeneous agricultural areas - Land principally occupied by agriculture 
with significant areas of natural vegetation" corresponding with the highest biocultural value related to chestnuts (Fig. 4).

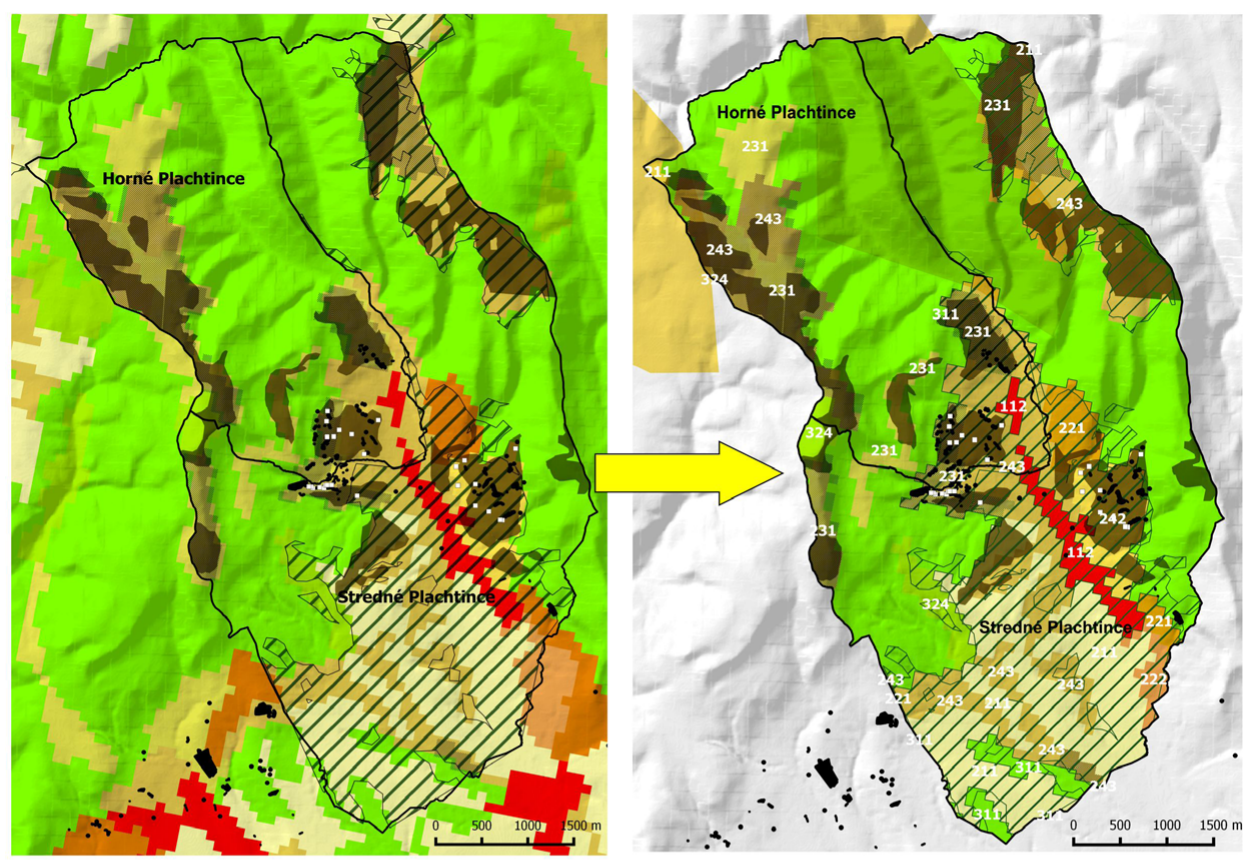

\section{Legend}

Corine Land Cover 2012 categories $\left(1^{1 t}-2^{x p}-3^{t /}\right.$ level):

Artificial surfaces - Urban fabric -Discontinuous urban fabric

Agricultural areas -Arable land - Non-irrigated arable land

Agricultural areas - Permanent crops - Vineyards

Agricultural areas -Permanent crops - Fruit trees and berry plantations

Agricultural areas -Pastures - Pastures

Agricultural areas - Heterogeneous agricultural areas - Complex cultivation patterns

Agricultural areas - Heterogeneous agricultural areas -

"Land principally occupied by agriculture, with significant areas of natural vegetation"

Forest and semi natural areas - Forests - Broad-leaved forest

Forest and semi natural areas - Scrub and/or herbaceous vegetation associations - Transitional woodland-shrub

Source:http://land.copernicus.eu/pan-european/corine-land-cover/clc-2012 corine-land-cover-1/@@redirect-download-url.

Individuals and areal formations of sweet chestnut (field research:2014-2016)

$\square$ Old stables (field research:2016)

Cadastral districts of Stredné and Horné Plachtince; Source:

https://kataster.skgeodesy.sk/eskn/services/NR/kn_wms_orto/MapServer/WmsServer?

Traditional rural landscape with scattered settlements

Traditional pastoral land with meadows

Source:http://nipi.sazp.sk/arcgis/services/atlassr/atlassr_05_rest/MapServer/WMSServer

High nature valuable farmland

Source: http://www.eea.europa.eu/data-and-maps/data/high-nature-value-farmland/

Habitats of European importance (Lowland Hay Meadows)

$\square$ DTM3-shaded; Source: https://zbgisws.skgeodesy.sk/zbgis_dmr3_wms/service.svc/get

\section{Legend}

Corine Land Cover 2012 categories $\left(1^{11}-2^{20}-3^{d}\right.$ level):

112 Artificial surfaces - Urban fabric - Discontinuous urban fabric

Agricultural areas - Arable land - Non-irrigated arable land

221 Agricultural areas - Permanent crops - Vineyards

222 Agricultural areas - Permanent crops - Fruit trees and berry plantations

231 Agricultural areas - Pastures - Pastures

Agricultural areas - Heterogeneous agricultural areas Complex cultivation patterns

243 Agricultural areas - Heterogeneous agricultural areas "Land principally occupied by agriculture, with significant areas of natural vegetation"

311 Forest and semi natural areas - Forests - Broad-leaved forest

324 Forest and semi natural areas - Scrub and/or herbaceous vegetation associations - Transitional woodland-shrub

Source:http://land.copernicus.eu/pan-european/corine-land-cover/clc-2012/ corine-land-cover-11@@redirect-download-url.

Individuals and areal formations of sweet chestnut (field research:2014-2016)

$\square$ Old stables (field research:2016)

Cadastral districts of Stredné and Horné Plachtince; Source:

https://kataster.skgeodesy.sk/eskn/services/NR/kn_wms_orto/MapServer/WmsServer?

Traditional rural landscape with scattered settlements

Traditional pastoral land with meadows

Source:http://nipi.sazp.sk/arcgis/services/atlassr/atlassr_05_rest/MapServer/WMSServer

High nature valuable farmland

Source: http://www.eea.europa.eu/data-and-maps/data/high-nature-value-farmland/

Habitats of European importance (Lowland Hay Meadows)

DTM3-shaded; Source: https://zbgisws.skgeodesy.sk/zbgis_dmr_wwms/service.svc/get

Fig. 4. A proposal of the boundary modification for the traditional landscape type. 
Chestnuts and old stables were observed also very close to the urbanized territories, this was the reason why also the CLC category 112 was included into a new area of the traditional landscape type containing the biocultural value related to chestnuts. Chestnuts were not found within 324 category (Forest and semi-natural areas - Shrub and/or herbaceous vegetation associations - Transitional woodland-shrub) indicating natural successive processes in the study area. This was the reason why the category was excluded from the proposal of the boundary modification of the given traditional landscape type.

\section{Discussion}

\section{Recommendations for the efficiency improvement of the field survey}

Quality of scientific and professional activity crucially depends on the technical and technological equipment used for gaining initial information on objects (Chudy et al., 2014). The field research was time-consuming. In this phase, we have not collected enough data about old stables from the field. To evaluate the nearest neighbours in the distance matrix, more than 40 buildings are required, while we had only 26 . Therefore, we respect a weakness of the explanatory power of the results. In the near future, we would like to continue in the field survey in order to complement the database of chestnuts and old agricultural buildings.

In addition, the accuracy of touristic GNSS (declination of more than 3 meters was observed) for the positioning of trees and old stables was insufficient, for instance, consequently to further data processing and the distance matrix calculation. Thus, we expect data collection and processing by modern, especially by contactless technologies in the future. The application of airborne and terrestrial light detection and ranging scanners, global satellite navigation systems (GNSS) and photogrammetry has led to an increase in the amount of data collected during the fieldwork (Rainato et al., 2013). Drone usage for forestry practices in recent years has brought several benefits. The most significant advantages are of much lower price than the manned aircraft, a possibility to achieve better resolution and the flexibility of use (Mokroš et al., 2016). The exact data on chestnut might be applied further for several purposes, for instance in monitoring of the chestnut health status (Michez et al., 2016) or for tree classification (Verlič et al., 2014).

The factors explaining the current occurrence and species composition of the local chestnut forests confirm their status as an anthropogenic habitat. The distribution of chestnuts in the present landscape is heavily linked to the past human settlements (Pezzi et al., 2011; Krebs et al., 2012). Similarly, Krčmářová and Arnold (2016) figured out that while the fruit systems could be located next to houses or right behind the gardens, the wooded pastures were more associated with forests and declared to be remote. The authors assumed that the systems would be kept in places where other systems did not bring their full yield and the trees compensated this hindrance (case of fruit agroforestry) or in places which were not suited for anything else in case of wood pastures. Such a case of fruit agroforestry would be a chestnut planting in pastures and meadows, close to old stables, in both the cadastral districts of Stredné Plachtince and Horné Plachtince. Chestnuts were frequently found in the vicinity of old stables (approximately from 80 to $200 \mathrm{~m}$ ) (Fig. 3). These findings partially confirmed 
the usage of chestnut products for cattle breading. Deeper social research would be expected to verify that chestnuts were an essential part of pastoral life of inhabitants in the study area.

\section{Concepts for the preservation of chestnut biocultural value in the landscape}

Agro-silvo-pastoral systems play many ecological, economic, social, and cultural functions and support landscape diversity (Bagella et al., 2014). The dynamics of rural landscape are triggered by socio-economic developments affecting the rural world. The techniques used in traditional societies, usually before the technological development of mechanization and chemical fertilizers, created valuable cultural landscapes where the strict relationship between man and the land over a long time period has accumulated values, stratifying them in the physical components of the territory (Agnoletti, 2006). Biocultural values could contribute towards the creation of diversified landscapes that transcend the accepted dichotomy between wilderness areas and cultivated fields. Within such local landscapes, local people may purposefully conserve the biodiversity which they value (Cocks, 2006).

Besides, sweet chestnut faces unfavourable living conditions in Slovakia. It interferes with traditionally used pastures and meadows, as we presented in the results. The chestnut occurrence coincides with the HNV farmlands and also with the habitats of European importance. Moreover, taking a lack of available data into consideration, we have confirmed the presence of chestnuts in the vicinity of old stables representing the cultural heritage.

Nevertheless, the old stables also constitute specific habitats of endangered animals - bats as we observed during the field survey (Fig. 5). All bat species are protected by the Act of National Council of the Slovak Republic No. 543/2002 Coll. on Nature and Landscape Conservation; Executive regulation No. 24/2003 and the European legislation (UNEP 1991). The widespread abandonment of various traditional woodlands and disappearance of traditional management practices have reduced the habitat diversity and have probably negatively affected the status of Leisler's bat in continental Europe (Szentkuti et al., 2013).

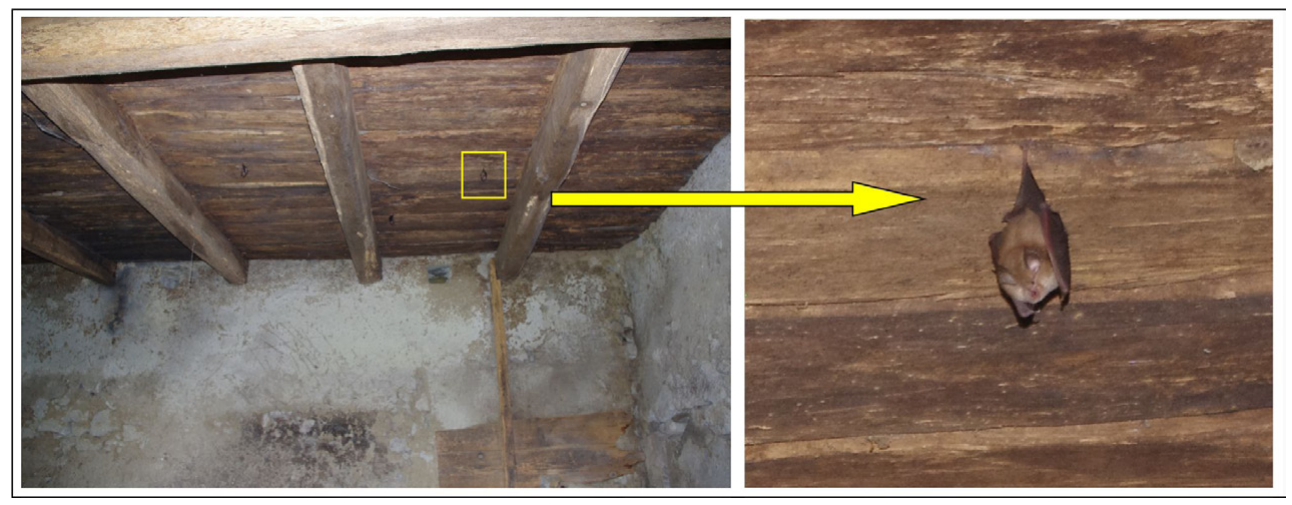

Fig. 5. Bat habitats inside the old stables. 
At this point, it is worth considering sweet chestnut to be an important factor supporting the landscape value as well as contributing to the landscape diversity and biodiversity.

Without a constant care (regular mowing and cattle grazing), chestnuts are heavily prone to damage and disease. They slowly decay and stop producing quality fruits (Michon, 2011). They face an inadequate maintenance in Slovakia. Currently, it has been strongly attacked by the parasitic fungus Cryphonectria parasitica Murr. Barr. causing the disease of chestnut blight and many populations suffer from necrosis (Juhásová et al., 2005). Nowadays, its preservation and protection according to the Act on Nature and Landscape Conservation is impossible as it is listed among the introduced tree species. A similar legal status of the chestnut protection is documented in Italy by Agnoletti (2007). The absence of chestnut groves in the list of habitats meriting a protection is mostly due to its artificial origin, but also for the assumed low biodiversity value of these woods as compared with natural forests.

If the preservation of heritage values is legally impossible in non-protected landscapes, this inevitably leads to the degradation of cultural landscapes and even to the degradation of cultural and natural values elsewhere, where they are protected by the law (Bloemers et al., 2010). Out of this situation, we can find a solution in the implementation of a multi-functional management of the rural landscape (Barbera, Cullotta, 2016), for instance, as the implementation of the knowledge of traditional fruit-tree planting in the landscape into the development of specific gentle tourism representing locally based values (Guisepelli et al., 2015).

\section{Conclusion}

In order to truly protect biodiversity, we need to think outside the scope of the economic model of asking how much a species is worthwhile or how useful it is to humans. The value of certain sites and species is often not quantifiable in monetary terms. Yet, does that give us the right to abuse these natural resources? (Djoghlaf, 2012) New emerging biocultural approaches are very much needed for strengthening the Western-style conservation management in biocultural diversity protection (Verschuuren, 2012).

We can conclude that sweet chestnut supports the value of the traditional landscape type with meadows and pastures. Chestnuts most frequently occurred in the extensively used CLC patches with "Agricultural areas - Pastures - Pastures" and with heterogeneous agricultural areas - "Land principally occupied by agriculture, with significant areas of natural vegetation", in parallel coinciding with the HNV farmlands and habitats of European importance and with the local occurrence of protected bat species.

We should preserve the diversity of European landscapes as a common resource of the natural and cultural heritage as defined in the European Landscape Convention (CoE, 2000). The findings of this work bring a new insight into the landscape values assessment and could be beneficial for the expected typology of cultural landscapes in Slovakia. Similarly, the proposed approach of the tree biocultural value assessment might be applied in different landscape types. 


\section{Acknowledgements}

This paper was financially supported by the Institutional Project Agency (Co. No. IPA TUZVO 01/2016), the project "Význam gaštaníc v agro-silvo-pastorálnych systémoch a hodnotenie zdravotného stavu gaštana jedlého s využitím bezpilotného lietadla”.

\section{References}

Agnoletti, M. (2006). Framing the issue - a trans-disciplinary reflection on cultural landscapes. In M. Agnoletti (Ed.), The conservation of cultural landscapes (pp. 3-29). London: CAB International. DOI: 10.1079/9781845930745.A.

Agnoletti, M. (2007). The degradation of traditional landscape in a mountain area of Tuscany during the 19th and 20th centuries: Implications for biodiversity and sustainable management. For. Ecol. Manag., 249, 5-17. DOI: DOI: 10.1016/j.foreco.2007.05.032.

Bagella, S., Caria, M.C., Farris, E., Rossetti, I. \& Filigheddu R. (2014). Traditional land uses enhanced plant biodiversity in a Mediterranean agro-silvo-pastoral system. Plant Biosystems, 150(2), 201-207. DOI: 10.1080/11263504.2014.943319.

Barbera, G. \& Cullotta S. (2016). The traditional mediterranean polycultural landscape as cultural heritage: Its origin and historical importance, its agro-silvo-pastoral complexity and the necessity for its identification and inventory. In M. Agnoletti \& F. Emanueli (Eds.), Biocultural diversity in Europe. Environmental history 5 (pp. 21-48). Switzerland: Springer. DOI: 10.1007/978-3-319-26315-1_2.

Bloemers, T., Daniels, S., Fairclough, G., Pedroli, B. \& Stiles R. (2010). Landscape in a changing world. Bridging divides, integrating disciplines, serving society. Strasbourg, Brussels: European Science Foundation ESF-COST.

Bolvanský, M., Brindza, J., Tóth, D., Bacigálová, K., Ferianc, P., Karelová, E., Harichová, J., Kačániová, M., Horčin, V., Mendel, L. \& Užík M. (2008). Gaštan jedlý (Castanea sativa Mill.) biológia, pestovanie a využívanie. Nitra: SPU.

Bounous, G., Paglietta, R., Peano, C., Giacalone, G. \& Parola F. (1999). The landscape value of chestnut grove in Cuneo Province (Italy). Acta Horticulturae, 494, 73-76.

Bounous, G. (2014). Perspectives and future of the chestnut industry in Europe and all over the world. Acta Horticulturae, 1043, 19-22. DOI: 10.17660/ActaHortic.2014.1043.1.

Chen, W.CH. \& Gilmore M. (2015). Biocultural rights: A new paradigm for protecting natural and cultural resources of indigenous communities. The International Indigenous Policy Journal, 6(3), Art. 3. DOI: 10.18584/ iipj.2015.6.3.3.

Chovanová, I., Paučová, A., Damjanovová, K., Botoš, A. \& Šujanová S. (2006). Urbanisticko-historický výskum a návrh zásad ochrany, obnovy a prezentácie hodnôt územia. Pamiatková zóna Horné Plachtince. Retrieved September 20,2016, from https://www.pamiatky.sk/Content/PZ_ZASADY/Horne_Plachtince/011-zasady_horne_ placht.pdf

Chudy, F., Sadibol, J., Slamova, M., Belacek, B., Beljak Pazinova, N. \& Beljak J. (2014). Identification of historic roads in the forest landscape by modern contactless methods of large-scale mapping. GeoConference on informatics, geoinformatics and remote sensing, 3, 184-190. DOI: 10.5593/SGEM2014/B23/S10.023.

Cocks, M. (2006). Biocultural diversity: Moving beyond the realm of 'Indigenous' and 'Local' people. Hum. Ecol., 34(2), 185-200. DOI: 10.1007/s10745-006-9013-5.

Conedera, M., Krebs, P., Tinner, W., Pradella, M. \& Torriani D. (2004a). The cultivation of Castanea sativa (Mill.) in Europe from its origin to its diffusion on a continental scale. Veg. Hist. Archaeobot., 13, 161-179. DOI: 10.1007/ s00334-004-0038-7.

Conedera, M., Manetti, M.G., Giudici, F. \& Amorini E. (2004b). Distribution and economic potential of the Sweet chestnut (Castanea sativa Mill.) in Europe. Ecol. Mediterr., 30(2), 179-193.

Conedera, M. \& Krebs P. (2008). History, present situation and perspective of chestnut cultivation in Europe. In C.G. Abreu, F.P. Peixoto \& J. Gomes-Laranjo (Eds.), Proceedings of the 2nd Iberian Chestnut Congress, Vila Real, 20-22 Feb 2007. Acta Horticulturae, 784, 23-27.

Conedera, M., Tinner, W., Krebs, P., De Rigo, D. \& Caudullo G. (2016). Castanea sativa in Europe: distribution, habitat, usage and threats. In J. San-Miguel-Ayanz, D. de Rigo, G. Caudullo, T.H. Durrant, \& A. Mauri (Eds.), European atlas of forest tree species (p.78). Luxembourg: Publication Office of the European Union. DOI: $10.2788 / 038466$

Council of Europe (COE) (2000). The European Landscape Convention - Firenze, 20.X.2000. Official Text in English 
and Explanatory Report. Strasbourg: Council of Europe. (ETS No.176).

Djoghlaf, A. (2012). Sacred species and sites. Advances in biocultural conservation. Foreword. In G. Pungetti, G. Oviedo \& D. Hooke (Eds.), Sacred species and sites. Advances in biocultural conservation (pp. 17-20). Cambridge: Cambridge University Press. DOI: 10.1017/CBO9781139030717.001.

Electronic Services of Real Estate Cadastre Portal (ESKN Portal) (2015). Cadastre of real estate. Retrieved July 3, 2016, from https://kataster.skgeodesy.sk/eskn/services/NR/kn_wms_orto/MapServer/WmsServe?

European Environmental Agency (EEA) (2016a). Corine land cover 2012. Retrieved July 3, 2016, from http://land. copernicus.eu/pan-european/corine-land-cover/clc-2012/corine-land-cover-1/@@redirect-download-url

European Environmental Agency (EEA) (2016b). High nature value (HNV) farmland. Retrieved July 3, 2016, from http://www.eea.europa.eu/data-and-maps/data/high-nature-value-farmland/

Franc, V. (2010). Contribution to the knowledge of Beetles (Coleoptera) in the surroundings of the Príbelce and Čebovce villages. In P. Urban \& M. Uhrin (Eds.), Príroda Príbeliec a širšieho okolia mikroregiónu Východný Hont (pp. 159-170). Zborník referátov z odbornej konferencie, 23.-24. 11. 2007. Príbelce, Banská Bystrica: Obecný úrad v Príbelciach, Univerzita Mateja Bela v Banskej Bystrici.

Galvánek, D. \& Lasák R. (2011). Informačný Systém Lúk DAPHNE - Mapovanie travobylinnej vegetácie Slovenska. 6510 Lowland Hay Meadows. Retrieved September 16, 2016, from http://n2k.daphne.sk/mapy/6510.pdf

GEOPORTÁL (2015). ZBGIS Map Client. Retrieved July 3, 2016, from https://zbgis.skgeodesy.sk/tkgis/default. aspx?lang=en/.

Guisepelli, E., Miéville-Ott, V., Perron, L., De Ros, G. \& Peyrache-Gadeau V. (2015). Landscape and sustainable development: A Union contrary to nature? In Y. Luginbühl, P. Howard \& D. Terrasson (Eds.), Landscape and sustainable development: the French perspective (pp. 95-108). Farnham: Surrey UK, Burlington, VT: Ashgate.

Heiniger, U. \& Conedera M. (1992). Chestnut forests and chestnut cultivation in Switzerland. In Proceedings of the International Chestnut Conference, 10-14 July 1992 (pp.175-178). Morgantown: West Virginia University.

Juhásová, G., Aadamčíková, K. \& Robin C. (2005). Results of biological control of chestnut blight in Slovakia. Phytoprotection, 86, 19-23. DOI: 10.7202/011710ar.

Keenleyside, C., Beaufoy, G., Tucker, G. \& Jones G. (2014). High nature value farming throughout EU-27 and its financial support under the CAP. Report Prepared for DG Environment. London: Institute for European Environmental Policy. (Contract No ENV B.1/ETU/2012/0035).

Kosňovská, J. (2013). The origin, archaeobotany and ethnobotany of sweet chestnut (Castanea sativa Mill.) in the Czech Republic. Interdisciplinaria Archaeologica, Natural Sciences in Archaeology, 4(2), 163-176.

Kozová, M., Otahel, J. \& Hrnčiarová T. (2009). Landscape classification - Methodological approaches and proposal of the Slovakia project. GeoScape, 4(2), 140-149.

Krčmářová, J. \& Arnold M. (2016). Traditional agriculture as cultural heritage. Forgotten agroforestry practices recorded in textual part of nineteenth century tax records. In M. Agnoletti \& F. Emanueli (Eds.), Biocultural diversity in Europe. Environmental History 5 (pp. 247-268). Switzerland: Springer. DOI: 10.1007/978-3-31926315-1_11.

Krebs, P., Koutsias, N. \& Conedera M. (2012). Modelling the eco-cultural niche of giant chestnut trees: new insights into land use history in southern Switzerland through distribution analysis of a living heritage. Journal of Historical Geography, 38(4), 1-15. DOI: 10.1016/j.jhg.2012.01.018.

Kuš́k, P. \& Pástor M. (2016). NATURA 2000 Sites in Velký Krtíš District (Slovakia). In Nature Conservation Investigations in NATURA 2000 Sites, in 'Sustainable Development in the Carpathian Basin III', Conference, 17-18 March 2016 (p. 57). Gödöllő: Szent István University, University Press.

Michon, G. (2011). Revisiting the resilience of chestnut forests in Corsica: from social ecological systems theory to political ecology. Ecology and Society, 16(2), 5.

Michez, A., Piégay, H., Lisein, J., Claessens, H. \& Lejeune P. (2016). Classification of riparian forest species and health condition using multi-temporal and hyperspatial imagery from unmanned aerial system. Environ. Monit. Assess., 188(3), 146. DOI: 10.1007/s10661-015-4996-2.

Miklós, L. \& Hrnčiarová, T. (Eds.) (2002). Landscape atlas of the Slovak Republic. Bratislava: MŽP SR, Banská Bystrica: SAŽP.

Mokroš, M., Tabačák, M., Lieskovský, M. \& Fabrika M. (2016). Unmanned aerial vehicle use for wood chips pile volume estimation. ISPRS - International Archives of the Photogrammetry, Remote Sensing and Spatial Information Sciences, XLI-B1, 953-956. DOI: 10.5194/isprs-archives-XLI-B1-953-2016.

National Forest Centre of the Slovak Republic (NFC) (2015). Forest geographical information system. Retrieved July 3, 2016, from http://gis.nlcsk.org/lgis/. 
Pástor, M., Bakay, L. \& Benčat’ T. (2015). Current state of chestnut (Castanea sativa Mill.) cultivation and occurrence in the Modrý Kameň area (Slovakia). In Shell fruit species, 10-11 November 2015 (p. 19). Gödöllő: National Agricultural Research and Innovation Centre, Budapest: NARIC Fruitculture Research Institute Budapest.

Pezzi, G., Maresi, G., Conedera, M. \& Ferrari C. (2011). Woody species composition of chestnut stands in the Northern Apennines: the result of 200 years of changes in land use. Landsc. Ecol., 26 (10), 1463-1476. DOI: 10.1007/ s10980-011-9661-8.

Rainato, R., Picco, L., Cavalli, M., Mao, L.L., Delai, F., Ravazzolo, M. \& Lenzi M.A. (2013). Evaluation of short-term geomorphic changes along the Tagliamento river. Journal of Agricultural Engineering. XLIV(s2), e15, 80-84. DOI: $10.4081 /$ jae.2013.

Slovak Environmental Agency (SEA) (2012). Traditional historical landscapes of the Slovak Republic. Retrieved April 18, 2016, from http://nipi.sazp.sk/arcgis/services/atlassr/atlassr_05_rest/MapServer/WMSServer.

Slovak Environmental Agency (SEA) (2015). Base maps. Historical maps. Retrieved April 18, 2016, from: http://tiles. geop.sazp.sk/base/service?

Špulerová, J., Dobrovodská, M., Štefunková, D., Piscová, V. \& Petrovič F. (2014). Evolution of the traditional agricultural landscape of Slovakia. In R. Efe \& M. Ozturk (Eds.), Environment and ecology in Mediterranean Region II (pp.133-146). Newcastle Upon Tyne: Cambridge Scholars Publishing.

Štefunková, D., Špulerová, J., Dobrovodská, M., Mojses, M. \& Petrovič F. (2013). Traditional agricultural landscapes - a model of detailed land use mapping. Tájökológiai Lapok, 11(1), 1-21.

Szentkuti, S., Bontadina, F., Spada, M., Moretti, M., Zambelli, N., Martinoli, A. \& Arlettaz R. (2013). Factors underlying migratory bat aggregations in chestnut groves. Endangered Species Research Journal, 21,105-114. DOI: $10.3354 /$ esr00496.

Tieskens, K., Schulp, N., Verburg, P. \& Kuemmerle T. (2014). D4.1 Typology of cultural landscapes. Report of the Hercules project. Retrieved August 10, 2016, from http://www.hercules-landscapes.eu/tartalom/HERCULES_ WP4_D4_1_VUA.pdf.

Torello Marinoni, D., Sartor, C., Ruffa, P., Akkak, A., Mellano, M.G., Beccaro, G.L., Bounous, G. \& Botta R. (2014). A multidisciplinary approach to preserve and value the chestnut heritage. Acta Horticulturae, 1043, 135-138.

United Nations Environment Programme (UNEP) (1991). Agreement on the conservation of populations of European Bats, EUROBATS. Retrieved August 18, 2016, from http://www.eurobats.org/official_documents/agreement_text

Verlič, A., Đurić, N., Kokal, Ž., Marsetič, A., Simončič, P. \& Oštir K. (2014). Tree species classification using WorldView - 2 Satellite Images and Laser Scanning Data in a Natural Urban Forest. Preliminary communication. Šmarski list, 9-10, 477-488.

Verschuuren, B. (2012) Integrating biocultural values in nature conservation: perceptions of culturally significant sites and species in adaptive management. In G. Pungetti, G. Oviedo \& D. Hooke (Eds.), Sacred species and sites. Advances in biocultural conservation (pp. 231-246). Cambridge: Cambridge University Press. DOI: 10.1086/671490. 